\section{Jurnal \\ Teknologi \\ MODELLING EROSION AND LANDSLIDES INDUCED BY FARMING ACTIVITIES AT HILLY AREAS, CAMERON HIGHLANDS, MALAYSIA}

\author{
A. F. Abdullaha, Aimrun W.a*, N. M. Nasidia, K. Hazari S. A. F.b, L \\ Mohd. Sidekc, Zalilah Selamatc \\ aDepartment of Biological and Agricultural Engineering, Faculty of \\ Engineering, UPM Serdang, Selangor, 43400 Malaysia \\ bZHL Engineers Sdn. Bhd., Presint Diplomatik 15, 62502 Putrajaya, \\ Wilayah Persekutuan, Malaysia \\ cUniversiti Tenaga Nasional, Institut Latihan Sultan Ahmad Shah, \\ 43000 Kajang, Selangor, Malaysia
}

Article history

Received

29 April 2019

Received in revised form

27 August 2019

Accepted

5 September 2019

Published online

24 October 2019

*Corresponding author aimrun@upm.edu.my

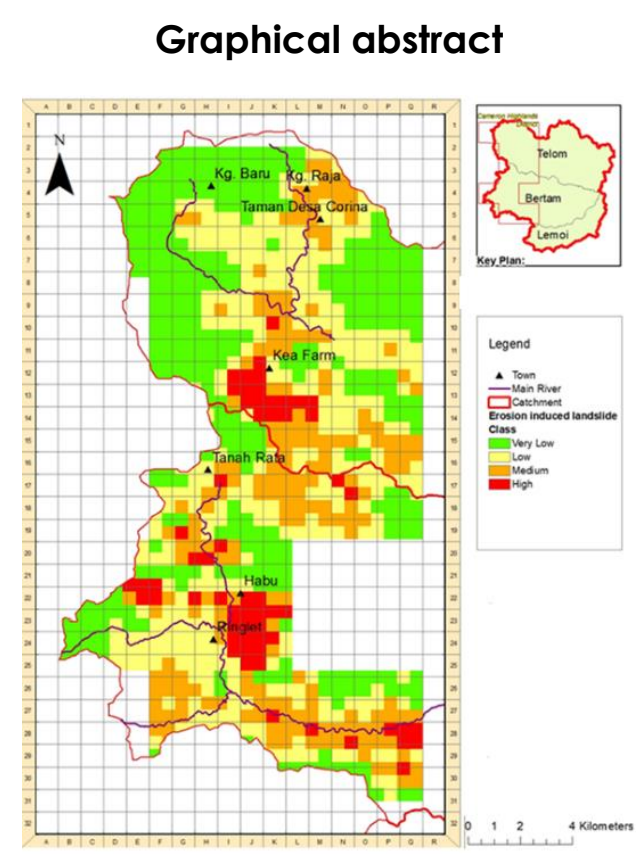

\begin{abstract}
This work was conducted at hilly farms of Cameron Highlands to model the incidences of soil erosion and landslides using historical data and field observations. IfSAR data with spatial resolution of $5 \mathrm{~m}$ was used which enable clear observation and delineation of the geographic features within the study area. Field visits were conducted to various places where landslides occurred on agricultural farms in order to validate the model. Also, the rate of soil erosions was evaluated using geospatial techniques. The potential landslide event and its probability of occurrence were combined using bivariate statistical analysis. The results revealed that most of the landslides incidents were occurred at areas with intensive agricultural activities with no proper erosion control measures. It was gathered that more than $75 \%$ of landslides occurred in agricultural activities areas are under sheltered farms. The annual soil erosion rates in both Telom and Bertom Catchments ware 38 ton /ha/year and 73.9 ton /ha/year respectively. It was revealed that, there is high risk of erosion-induced landslides in agricultural farms. However, the erosion induced landslide map shows that most the landslide occurred close to the rivers. This indicated that both agricultural operations and proximity to rivers are influencing factors for the incidences.
\end{abstract}

Keywords: Farming activities, soil erosion, landslide, sediment, geospatial

\title{
Abstrak
}

Kerja ini dijalankan di kawasan ladang berbukit terletak di Cameron Highlands untuk memodelkan hakisan tanah dan tanah runtuh menggunakan data sejarah dan pemerhatian lapangan. Data IfSAR dengan resolusi spasial $5 \mathrm{~m}$ telah digunakan untuk membolehkan pemerhatian dan penentuan ciri-ciri geografi dalam kawasan kajian dengan jelas. Lawatan lapangan dijalankan ke pelbagai tempat di mana tanah runtuh berlaku di ladang pertanian untuk mengesahkan model ini. Juga, kadar hakisan tanah dinilai menggunakan teknik geospatial. Kejadian tanah runtuh yang berpotensi dan kebarangkalian berlaku kejadiannya digabungkan menggunakan analisis statistik bivariat. Hasil kajian menunjukkan bahawa kebanyakan kejadian tanah runtuh berlaku di kawasan yang mempunyai aktiviti pertanian intensif tanpa langkah kawalan hakisan yang betul. la dapat dirumuskan bahawa lebih daripada 75\% tanah runtuh berlaku di kawasan-kawasan aktiviti pertanian di bawah 
ladang terlindung. Kadar hakisan tanah tahunan di lebaran Telom dan Bertam masing-masing berjumlah 38 tan/ha/tahun dan 73.9 tan/ha/tahun. la juga telah mendedahkan bahawa, terdapat risiko tinggi tanah runtuh akibat dari hakisan tanah di ladang pertanian. Walau bagaimanapun, peta tanah runtuh akibat hakisan menunjukkan bahawa kebanyakan tanah runtuh berlaku berhampiran sungai. Ini menunjukkan bahawa kedua-dua operasi pertanian dan berdekatan dengan sungai mempengaruhi faktor-faktor untuk kejadian ini.

Kata kunci; Aktiviti perladangan, hakisan tanah, tanah runtuh, sedimen, geospatial

(C) 2019 Penerbit UTM Press. All rights reserved

\subsection{INTRODUCTION}

Landslide is a natural disasters typically occur as a results of mass movement of earth, rocks, debris, or mud down a slope. It often associated with triggering factors such as an earthquake, a large storm, erosion or rapid snowmelt [1]. A landslide event usually occurs in multiple incidences that claims human lives, properties or both [1, 2]. The term "landslide" encompasses five methods of slope movement: falls, topples, slides, spreads, and flows. These are further segmented by the nature of geologic material into; bedrock, debris and earth [2, 3].

Moreover, the debris flows, commonly referred to as mudslides is an example of the most common landslides (Figure 1). In a global context, landslides are referred as "mass wasting" which symbolizes any form of down-slope movement of soil and rock under direct influence of gravity [3]. However, excessive cultivation of highland areas inspires high runoff generation which eventually led to excessive soil erosion. Consequently, it deteriorates the ground slopes and exacerbates the processes of landslides [4].

In recent times, more hilly lands were opened and leveled for intensive crop production at Cameron Highlands. Although, the overall agricultural coverage is relatively small but mostly done on steep slopes [4]. [5] reported that, the high usage of fertilizer and pesticides by local farmers, accompanied by increased frequency of major storms had given rise to high soil erosion and environmental pollution. This causes a serious soil erosion which produce large amounts of sediments and increases risk of landslides [3]. The resulting sediments are then transported and deposited in the storage dam or river networks. Hence, reduces the active storage capacity and eventually shortening life span of the reservoirs. In addition, the reduced reservoirs may eventually lead over flooding, erosion and landslides.

Nowadays, geospatial techniques have greatly assist for assessing risk level of many environmental hazards, including landslides. [6] used GIS-based techniques to determine landslide susceptibility and found that, about $70 \%$ of the area is located within high and very high susceptibility zone. This signifies that majority of the occupants are leaving in danger of being destroyed in future due to landslides. Similarly, [2] conducted future assessment of landslides and soil erosion events on sediment resources in Thailand from economic outlooks. The results showed huge economic lost to affect the people due to expected annual landslide damages which requires necessary proactive measures.

However, susceptibility mapping provides evidence about vulnerable locations and helps to potentially reduce infrastructure damage due to mass wasting. Thus, the ability to discover the lithology layer and slope aspects is essential to detect possible occurrence of landslides being the most dominant factors of landslide [7]. The direct impact of landslides on household income was estimated in tropical regions of Uganda in order to investigate the presence of specific risk sharing and mitigation strategies towards landslides [8]. The study revealed that, the income of affected households by landslides is considerably reduced. The households that are affected by recent landslides are mostly participated in self-employed activities. The poverty incurred was attributed to non-relief materials to compensate for the huge economic loss from agriculture.

Therefore, the aim of this study was to develop a landslide susceptibility model which will disclose the influence of soil erosion from agricultural farms on the occurrence of landslides at Cameron Highlands. This could be achieved through conducting an inventory survey and field study on soil erosion and landslide affected areas. This helps to identify and establish erosion-induced landslides risk maps. Other factors such as proximity to river, sheltered and open farming systems as they contribute to the problem were examined appropriately. 


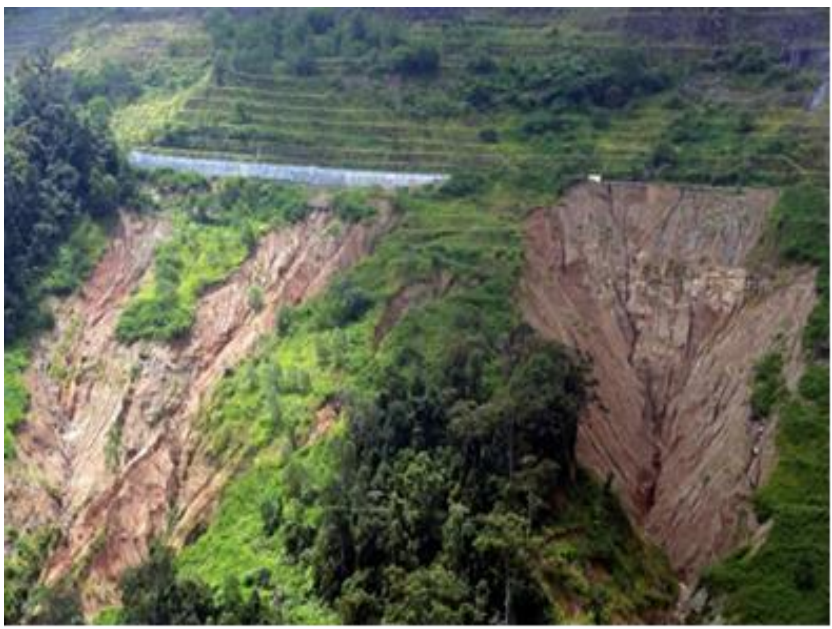

Figure 1 A typical Landslide incident at Cameron highlands

\subsection{METHODOLOGY}

\subsection{Location of Study Area}

This study was conducted at Cameron Highlands, a district in Pahang, Malaysia. It is considered as one of the most important hill stations in the country which occupies an area of 712.18 square kilometers and situated on Latitude of $4.28^{\prime} \mathrm{N}$, and Longitude of 101.23'E [5]. The highlands shared boundaries to Kelantan and Perak from the north and west respectively. The major towns located within Cameron Highlands are Ringlet, Tanah Rata, Brinchang and Kampung Raja. The highlands lied on altitude between $1070 \mathrm{~m}$ and $1830 \mathrm{~m}$ above mean sea level [9]. The natural weather condition of Cameron Highlands provides opportunity for agricultural activities and many tourist attractions such as tea plantations, tea factories, rose gardens, strawberry farms, natural waterfalls, golf courses and aging colonial-style living homes offering a historical memory.

\subsection{Landslide Incident Inventories}

Historical landslide inventories refer to the total sum of many landslide events that have occurred over time period. The landslide inventory was prepared from historical records, remote sensing and field data measurements. High-resolution SPOT fused images and aerial photo $(0.1 \mathrm{~m})$ were used for the visual detection of landslides in the study area. Since some landslides may occur under vegetation or in areas that are invisible in the satellite images, those landslides incidences were gathered by field measurements (for new landslides) and historical records (for old landslides).

Inventory data published by the Department of Mineral \& Geoscience Malaysia (Malay: Jabatan Mineral \& Geosains Malaysia, JMG) showed that most of the landslide incidents had occurred at areas with intensive agricultural activities, proving that anthropogenic activities are among the major contributors to soil erosion and landslides occurrences.

Field studies were conducted in order to examine new landslides which were not in the recorded dataset. For example, Figure 1 illustrates a newly case of landslide at the period when the study was on going. The location of such incidences was recorded using GPS device and the number was added to that obtained from Department of Mineral \& Geoscience Malaysia. Through this process, a total of 625 landslides incidents were generated for the analysis. Moreover, the activity of each location was assessed and classified either agricultural or non-agricultural area. Depending upon the activity in the surrounding landslide location, whenever the location of the landslide is at farm or downstream of the farm meaning that, the drains are flowing towards the point, such incidents are counted as part at farming area. Otherwise, is counted as a landslide at nonagricultural area.

\subsection{Soil Loss Estimation using Universal Soil Loss Equation (USLE)}

Water is the main agent responsible for soil erosion in Malaysian climate and causes many forms environmental degradation [10]. This problem includes soil erosion, sedimentation of rivers and frequent flooding [3]. Sedimentation and soil erosion include the processes of detachment, transportation and deposition of solid particles also known as sediments [11]. The forms of water responsible for soil erosion are raindrop impact, runoff and flowing water [12]. Erosion from mountainous areas and agricultural lands are the major source of sediment transported by streams and deposited in reservoirs, flood plains and deltas [13]. Sediment load is also generated by erosion of beds and banks of streams, the mass movements of sediment such as landslides, rockslides and mud flows, as well as by construction activity of roads, buildings and dams [7].

The annual average erosion from a given geographical area and time could be computed by using USLE (Equation 1). USLE is an erosion model developed by the United States of America, Department of Agriculture to support decision making in soil conservation planning and management. The model was further modified to improve the prediction accuracy and to be applicable universally. The revised universal soil loss equation (RUSLE) has the same factors as the former, except that in each element, efforts were made to involve many more influencing factors in order to make it widely applicable in many field $[10,11]$. Both USLE and RUSLE are being used to compute computes the average annual soil.

$$
A=\text { R. K. LS. C.P }
$$

Where: $\mathrm{A}=$ annual soil loss (tones/ha/year) $\mathrm{R}=$ rainfall factor (MJ-mm/ha/ha/year) 
$\mathrm{K}=$ soil erodibility factor (ton hour $/ \mathrm{MJ} / \mathrm{mm}$ )

$L \times S=$ slope length and steepness factors, respectively (dimensionless)

$C=$ vegetation and management factor (dimensionless)

$\mathrm{P}=$ support practice factor (dimensionless)

The Modified Universal Soil Loss Equation (MUSLE) is another improvement made in the same direction of quantifying the sediment load [10]. MUSLE is perhaps the most frequently used equation for sediment yield estimation to calculate sediment yields from a catchment area as a result of a specific storm event (Equation 2).

$$
Y=89.6\left(V_{p}\right)^{0.56}(\text { K. LS. C. P) }
$$

Where:

$Y \quad=S e d i m e n t$ yield per storm event (tons)

$\checkmark \quad=$ Runoff volume $\left(\mathrm{m}^{3}\right)$

$Q_{p} \quad=$ Peak Discharge $\left(\mathrm{m}^{3} / \mathrm{s}\right)$

$\mathrm{K}, \mathrm{LS}, \mathrm{C}$ and $\mathrm{P}$ have the usual meaning

\subsection{Rainfall Erosivity Factor (R)}

Long time hydrological data (more than 30 years) was obtained from the Hydrological Station of the Department of Irrigation and Drainage (DID) Malaysia. The data available was in days and from eight meteorological stations within the study area (Table 1). In this study, equation proposed by Bols [14] was used to calculation of the rainfall erosivity factor ( $R$ factor) based on empirical study (Equation 3). The annual precipitation was collected together with geographical locations from each meteorological station and applied in the equation.

$$
R=2.5^{*} P 2 /(100(0.073 P+0.73))
$$

Where; $\mathrm{P}$ is annual precipitation in $\mathrm{mm}$

\begin{tabular}{|c|c|c|c|}
\hline $\begin{array}{l}\text { Meteorologic } \\
\text { al Station }\end{array}$ & Longitude & Latitude & $\begin{array}{l}\text { Annual } \\
\text { Precipita } \\
\text { tion } \\
(\mathrm{mm})\end{array}$ \\
\hline Telanok & $101 \circ 31^{\prime 2} 25.36$ '" & $4 \circ 21^{\prime} 16.63^{\prime \prime}$ & 2308.25 \\
\hline Tanah Rata & $101 \circ 22^{\prime} 36.42^{\prime \prime}$ & $4 \circ 28^{\prime} 12.45^{\prime \prime}$ & 2453.63 \\
\hline Mardi & $101 \circ 23^{\prime} 06.72^{\prime \prime}$ & 4०28'06.73'" & 2425.26 \\
\hline Terisu & $101^{\circ} 29^{\prime} 20.80^{\prime \prime}$ & 4031'26.86'" & 1886.09 \\
\hline Raja & $101 \circ 24^{\prime} 34.61^{\prime \prime}$ & 4033'59.01"' & 2308.27 \\
\hline Alurmasuk & $1011^{\circ} 28^{\prime} 45.49^{\prime \prime}$ & $4030^{\prime} 43.18^{\prime \prime}$ & 1756.93 \\
\hline Ladang teh & $1011^{\circ} 24^{\prime} 58.43^{\prime \prime}$ & $4030^{\prime} 56.13^{\prime \prime}$ & 2327.73 \\
\hline Kajiklim Habu & $101 \circ 23,28.65^{\prime \prime}$ & $4026^{\prime} 23.43^{\prime \prime}$ & 2285.15 \\
\hline
\end{tabular}

Table 1 Annual Precipitation for each Meteorological Station

\subsection{Soil Erodibility Factor (K)}

Soil erodibility factor represents soil component in erosion studies and is a function of geology type. The geology data was derived from Peta Geologi Semenanjung Malaysia provided by Jabatan Mineral dan Galian, 2004. There are basically two types of geology in Cameron Highland which are Intrusive rocks and Silurian Ordovician [15]. K-Factor is a function of percentage of silt and coarse sand, soil structure, permeability of soil and the percentage of organic matter contain. $\mathrm{K}$ factor is a measure of soil resistance against erosion agents and is determined based on the soil type [16]. Table 1 presents $K$ values for the two classes which were used for this study and are extracted from the Agricultural Handbook $[17,18]$. Table 2 presents various soil types and the corresponding $\mathrm{K}$ factor as used in this study.

Table 2 Soil types and their K factor values

\begin{tabular}{lc}
\hline Soil series (types) & K-factor \\
\hline Serong & 0.1144 \\
Selangor kangkong association & 0.07 \\
Rengam & 0.09 \\
Kuala-kedah permatang association. & 0.1125 \\
Steep land & 0.1100 \\
Rengam bukit temiang association & 0.1159 \\
Local alluvium-colluvium association & 0.1137 \\
Urban land & 0.1102 \\
\hline
\end{tabular}

\subsection{Topographic Factor (LS)}

Topographic factors represent the combined effect of slope length (L) and slope steepness (S). L and S factors are often used together because they all translate the energy due to gravity associated with flow. The amount of erosion increases with increases in slope length $[12,19]$. The slope length is described as the distance along the flow path, from the origin of overland flow down to the point where deposition begins to occur (on concave slopes) or to a point of flow concentration [16]. In USLE model, the effects of rill and inter-rill erosion are represented together. But rill erosion is mainly caused by surface runoff and increases downslope because the runoff increases in this direction. While, Inter-rill erosion is occurred primarily from raindrop impact and uniformly along a slope length. Therefore, the $L$ factor is greater for those conditions where rill erosion tends to be greater than inter-rill erosion. Erosion increases with slope steepness but, in contrast to the $L$ factor representing the effects of slope length, the USLE makes no differentiation between rill and inter-rill erosion regarding the S factor that computes the effect of slope steepness on soil loss. These factors are typically calculated together for input into the equation (Equation 4).

$L S=\left(\text { Flow Accumulation } \times \frac{\text { Cell Size }}{22.13}\right)^{0.4} \times \sin \left(\frac{\text { Slope }}{0.896}\right)^{1.3}$

\subsection{Land Cover Management and Conservation} Factors ( $\mathrm{C}$ and $\mathrm{P}$ )

The C-factor represents the combined effect of cover and management variables and all other interrelated materials covering soil surface that prevent direct contact of raindrop [12]. It is basically derived from a land use/cover classification from the satellite data. A 
land use/cover map was normally prepared using satellite images (usually $10 \mathrm{~m}$ spatial resolution). Then a supervised classification method is applied to the image followed by field survey in order to extract ground truth data for verification [18]. This method utilizes geospatial tools to estimate the amount of soil loss for a certain study area. This study uses $C$ and $P$ datasets already prepared and documented in erosion control guideline by [20]. Table 3 presents land cover management and conservation factors in Cameron Highlands in accordance with the erosion control guidelines.

Table 3 Cover Management Factor (C) and Conservation Practice (P)

\begin{tabular}{lclc}
\hline $\begin{array}{l}\text { Erosion } \\
\text { Control }\end{array}$ & C Factor & $\begin{array}{l}\text { Erosion } \\
\text { Control }\end{array}$ & P Factor \\
\hline $\begin{array}{l}\text { Mining Areas } \\
\text { Agricultural }\end{array}$ & 1.00 & $\begin{array}{l}\text { Bare soil } \\
\text { Disked bare } \\
\text { soil }\end{array}$ & 1.00 \\
$\begin{array}{l}\text { Areas } \\
\text { Agricultural }\end{array}$ & 0.38 & $\begin{array}{l}\text { Sand bag } \\
\text { barriers } \\
\text { Crops }\end{array}$ & 0.90 \\
$\begin{array}{l}\text { Horticulture } \\
\text { Cocoa }\end{array}$ & 0.25 & $\begin{array}{l}\text { Grass buffer } \\
\text { strips }\end{array}$ & 0.80 \\
Coconut & 0.20 & $\begin{array}{l}\text { Basin slope } \\
\text { (\%) }\end{array}$ & \\
Oil to 10 & \\
Oil Palm & 0.20 & 0.24 & 0.60 \\
Rubber & 0.20 & & 0.80 \\
\hline
\end{tabular}

\subsection{Landslides Susceptibility and Zoning}

The main factors of consideration for landslide modelling were geology, slope and average annual rainfall [21]. These three factors play significant role for in determining the extent of landslides occurrences [18]. In order to determine the areas most threatened by landslides, two approaches have been used so far: field surveys based on observations and bibliography [22]. Through appropriate statistical analysis and geospatial weighting, the landslide susceptibility maps were developed. Also, in order to validate the model perimeters, appropriate feedback is required (Figure 2). Bivariate Statistical Analysis in ArcGIS was used to come up with statistics about area under risks of erosion and landslides. All the data were prepared in form of maps using GIS software for modelling. Each factor was assigned a weight through reclassification depending on the impact on landslide occurrences. The weighting was made according to landslide susceptibility Map by USGS, California Geological Survey (2011). Multiple field campaigns were conducted using precise GNSS device that receives real-time corrections from Malaysian Survey Department. In field survey, the location of fresh landslide scars was identified and mapped. This is how we gather the total number of 625 samples with their associated attributes and prepared it for geospatial analysis. Finally, the landslides susceptibility zoning was developed.

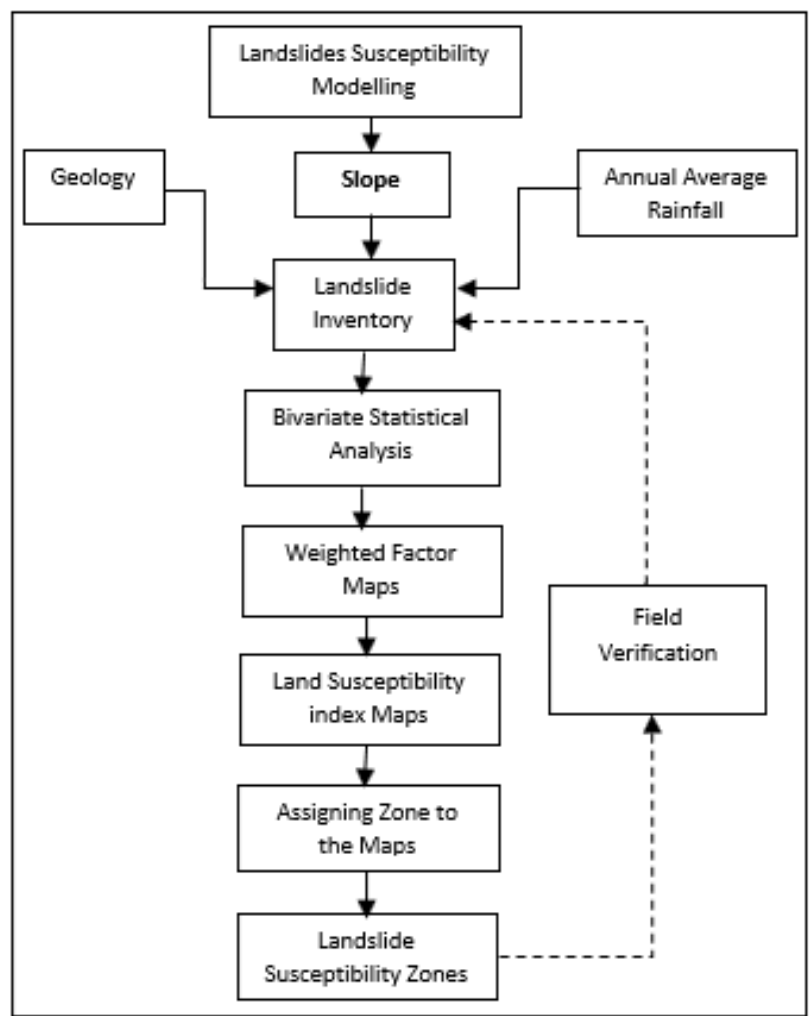

Figure 2 Landslide Susceptibility Flow chart

\subsection{Erosion-Induced Landslides}

Soil erosion was computed using RULSE model and all the parameters were obtained as indicated by the flow chart in Figure 3. The Erosion Induced Landslide Risk Modelling was developed to produce the Erosion Induced Landslide in order to visualize the extent of risk associated with faming activities in the study area. The modelling was done by taking into consideration of both landslide susceptibility and soil erosion information for the project, which involves combining output from Figure 2 and 3 together. In the effort to produce erosion Induced Landslide Risk map, the potential landslide event and its probability of occurrence were combined using bivariate statistical analysis in ArcGIS. Firstly, the landslide susceptibility map was produced based on the historical records in the project area for 20 years and frequency ratio model using map overlaying techniques. Then the landslide susceptibility map was overlaid on the soil erosion map of the project area that was developed based on the USLE to produce the Erosion-Induced Landslide Risk Map. This process has been used by some already published researches, e.g. [23-26]. 


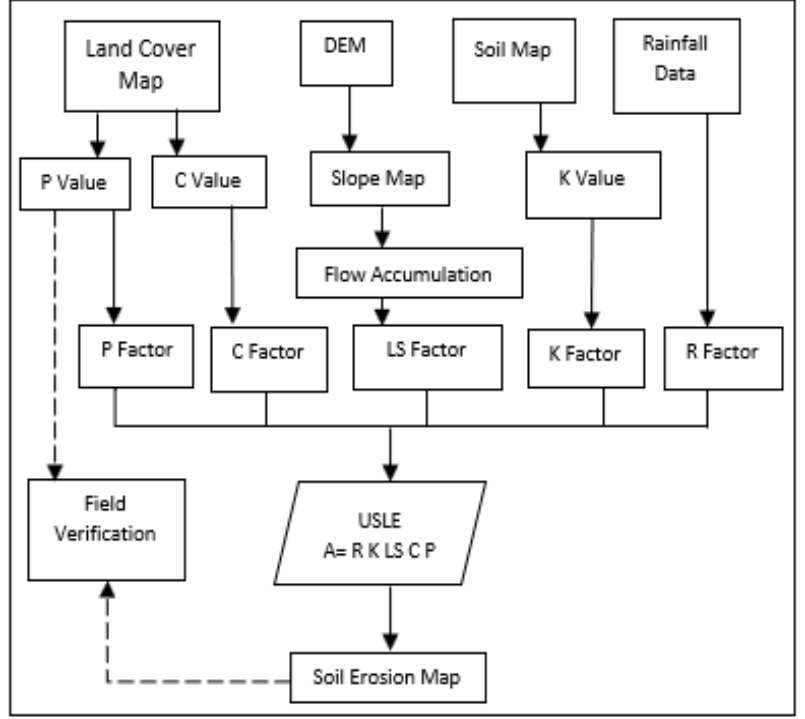

Figure 3 Flow chart for soil erosion map

\subsection{RESULTS AND DISCUSSION}

\subsection{Erosion and Landslides Inventory}

The landslide inventory was prepared from historical records, remote sensing and field measurements [2729]. The study separates the landslides in to three parts depending on the farming area occurred. Soil erosion information about the rate each area was quantified in order to make comparison with the inventory data. The results reveal that, there is a good relationship between frequency of landslides and soil erosion rate in the agricultural practicing area.

In other hand, Agricultural practices in Cameron Highland is basically divided into three types; terracing, contouring and sheltered farming [30]. Figure 4 shows that, about $58 \%$ of farming practices in Cameron Highland are performed under sheltered farming, followed by contouring $(27 \%)$ and terracing (15\%) [5]. The tea cultivation is now on the decline due to labor shortages, and in some areas, it is being replaced by vegetables. Three popular vegetable types in Cameron Highlands are cabbage, Chinese cabbage and tomato. Flower cultivation has increased recently, sometimes the flower is grown at the expense of vegetables, and three major flower species grown in Cameron Highland were chrysanthemum (52\%), carnation (20\%) and rose (18\%).

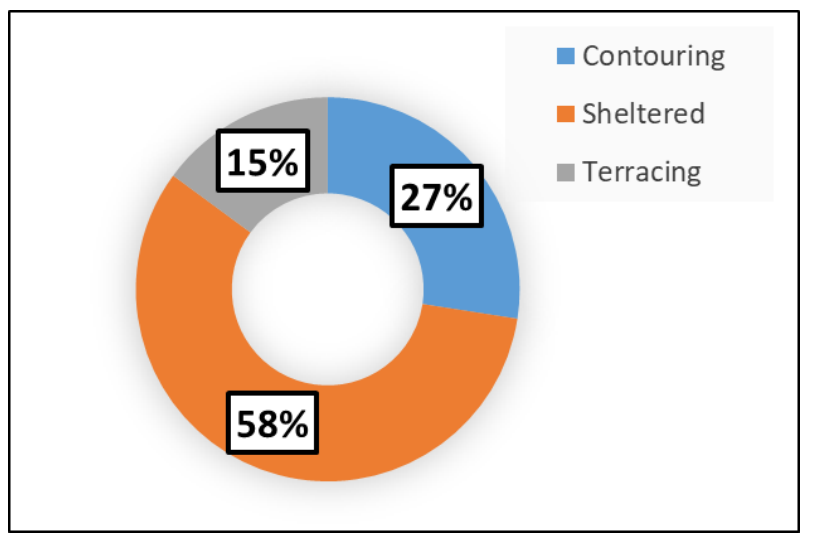

Figure 4 Agricultural practices in Cameron Highlands

The annual crops are planted on both terraces and platforms built on steep slopes or hilltops. Figure 5 shows that, only about $17 \%$ of the total study area is below $15^{\circ}$ while $23 \%$ of the area is between $15^{\circ}$ to $20^{\circ}$. Furthermore. The highest percentage of the terrain $(32 \%)$ area is within the slopes of $20^{\circ}$ to $25^{\circ}$ and the steepest slope found in this area is as large as 80.2 degree. As mentioned earlier, almost $59.7 \%$ of the hillsides happened in Cameron Highland were found to be at a slope gradient greater than $20^{\circ}$. This signifies that surrounding areas of the landslide are hilly to very steep [4].

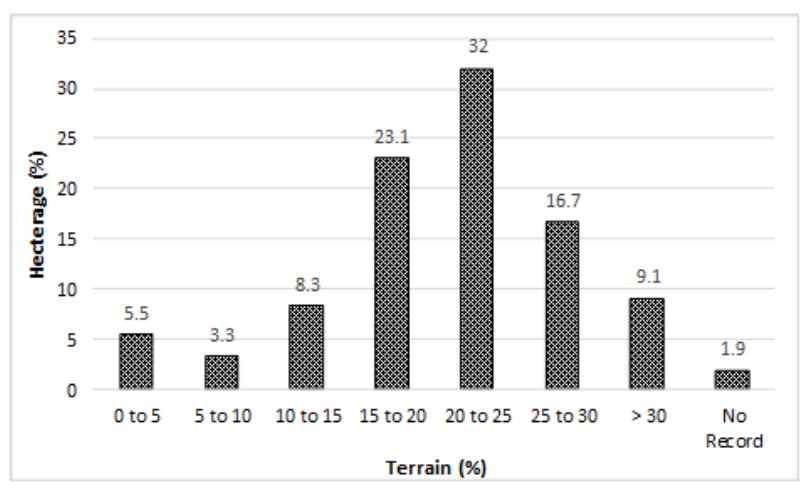

Figure 5 Terrain classes at Cameron Highlands

Further, Figure 6 presents the rates of landslide occurrence at both agricultural and non-agricultural areas based on the data provided by the Department of Mineral \& Geoscience. From the total of 625 landslides incident recorded in Cameron Highlands, $48.16 \%$ occurred in agricultural farming areas, while $52 \%$ occurred in agricultural related zones. Moreover, it is estimated that out of the landslide incidents in agricultural areas, $75.42 \%$ happened in areas with sheltered farm and $17.94 \%$ occurred in terracing farms [18]. Figure 7 shows a typical landslide, inventory data and agricultural practices under which the landslides occurred. This analysis is based on data provided by the Department of Mineral \& Geoscience, Malaysia and the site inspections conducted at the Cameron Highland areas. 


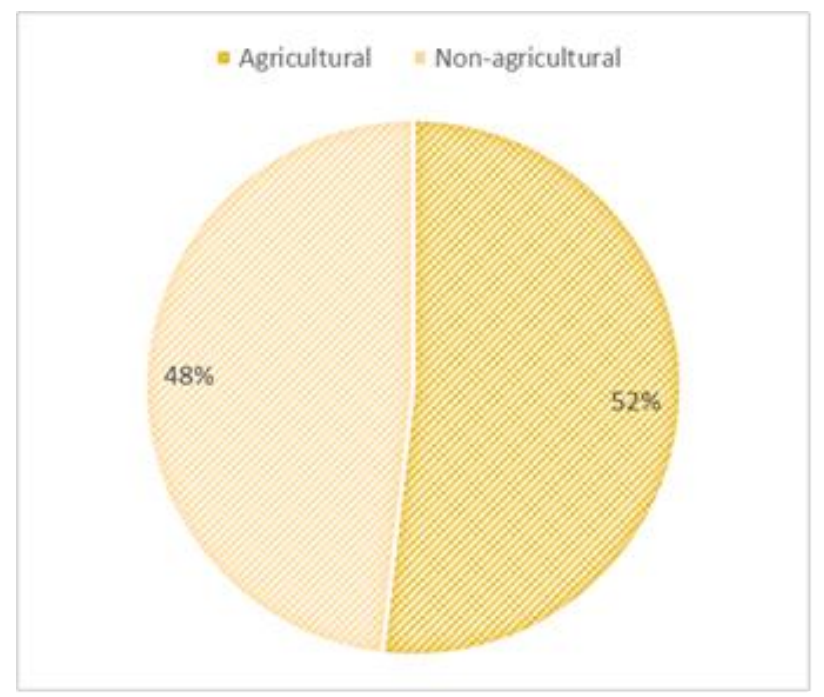

Figure 6 Inventory data on landslide incidents at Cameron Highlands

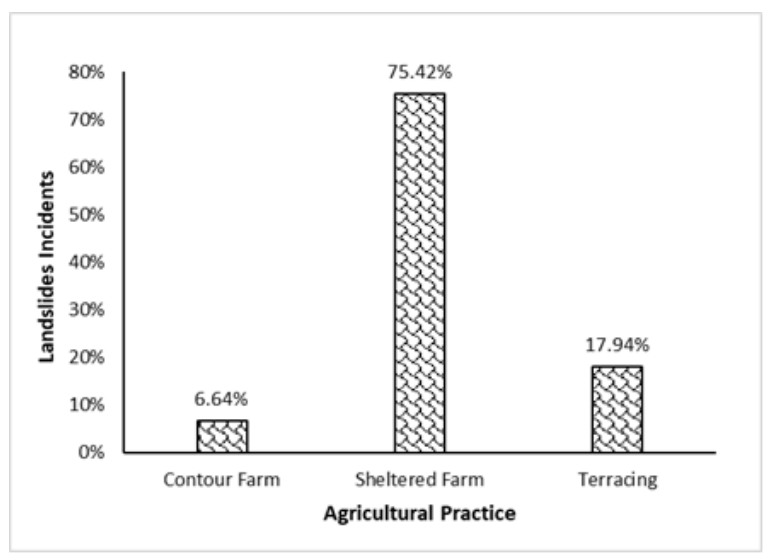

Figure 7 Landslides under different agricultural practices

The implications of soil erosion by water in Cameron highlands extend beyond the removal of valuable topsoil [21]. Crop emergence, growth and yield are also directly affected by the loss of natural nutrients and applied fertilizers. Seeds and plants can be disturbed or completely removed by the erosion. Organic matter from the soil, residues and any applied manure are relatively lightweight and can be readily transported off the field, particularly during high rainfall intensity conditions. Pesticides may also be carried off the site with the eroded soil. Soil quality, structure, stability and texture can be affected by the loss of soil. The breakdown of aggregates and the removal of smaller particles or entire layers of soil or organic matter can weaken the structure and even change the texture. Textural changes can in turn affect the water-holding capacity of the soil, making it more susceptible to extreme conditions such as drought.

\subsection{Soil Loss due to Erosion}

Computation of the factors contributing to soil loss which comprised of main input to the RUSLE model for erosion assessment were achieved using the normal procedures as discussed above, as well as in many literatures. The soil erosion map (Figure 8) of the study area was generated by cell to cell multiplication overlay of the raster maps of the six RUSLE input parameters (rainfall erosivity, soil erodibility, conservation practice, slope gradient, slope length and cropping and management factors). From the soil erosion assessments, the two catchments studied were Telom and Bertam. From the analysis, the soil loss by erosion from these catchments were $38.0 \mathrm{t} \mathrm{ha}^{-1}$ year-1 and 73.9 t ha $^{-1}$ year-1 respectively. Comparing with erosion classification [8] and many existing studies (e.g. [6, 28, 29], the soil erosion in Cameron highlands is at high side and attention is needed [15]. It is clearly observed that all the cases of erosion were occurred in western part of the study area, this is due to the fact that most of the developed lands are located in the west and the agricultural activities are carried out there too. Kea farm and surrounding areas are affected with high erosion events, though are located at the border of the two catchments. Other places fall under high erosion incidents are Habu, Tena Rata and Ringel which all are within Telon catchment. Majority of agricultural activities in Cameron Highlands are conducted within the above-mentioned places [15], which are affected by high rate of soil erosion. However, the regions under low and moderate erosion rates include Hulu Telom, Kangin Rata, Kangi Baru and Taman Desa. Generally, it appears that all the high erosion affected areas are found under agricultural practicing area due to excessive soil disturbance, exposure of soil surface to splash erosion coupled with high slopes, which exacerbate the erosion processes. In contrast, the study shows that low soil erosion emerges from non-agricultural lands, undisturbed soil, and forest. 


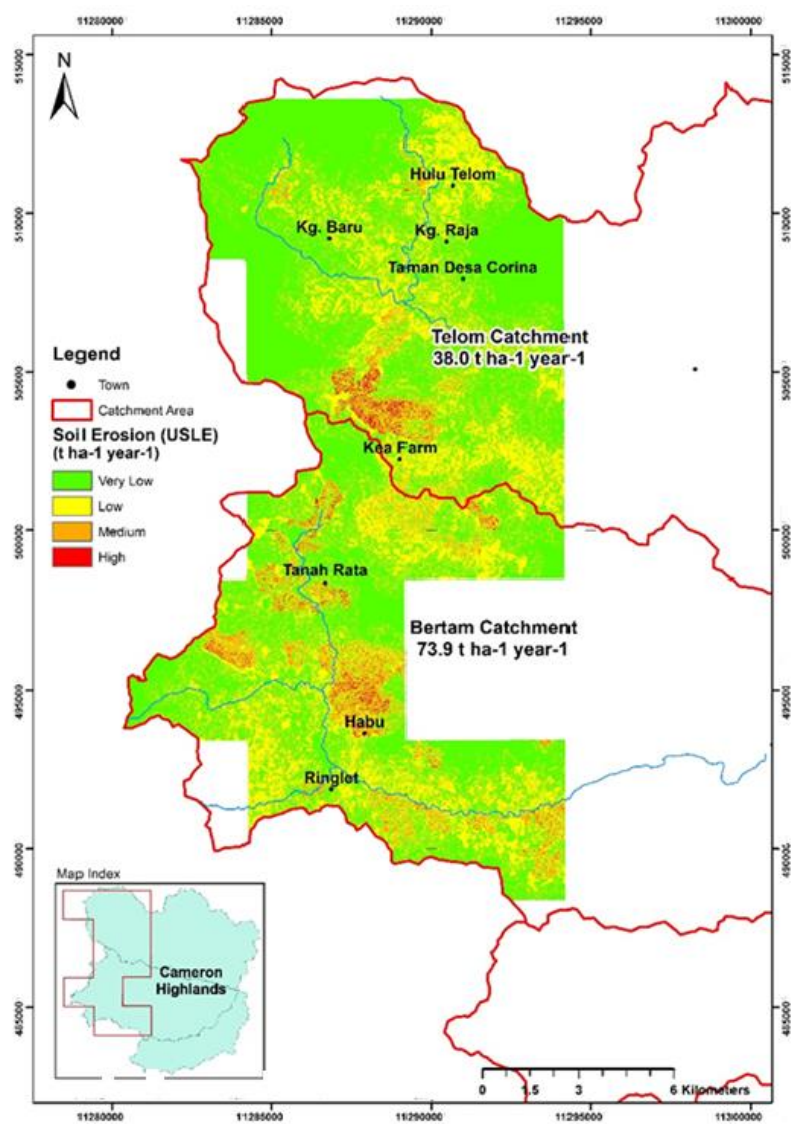

Figure 8 Soil erosion in the study area

\subsection{Landslide Susceptibility}

Land Susceptibility Index was developed based on the slope, average annual rainfall, geology and landslide Inventory data by assigning weighted for the individual factors. Zones are then assigned to individual factors and normalized using overlay function in GIS $[6,31]$. At the end of the analysis, landslide susceptibility map was developed as presented in Figure 9. The results reveal that most of the landslide events happened in geology type Silurian Ordovician. Further, landslide incidents occurred in the areas where the slopes are in the range of 8 to 19 degree coupled with average annual rainfall of higher than $2,500 \mathrm{~mm}$. Unlike soil erosion, there is large area falls under high landslide susceptible zones in both Telom and Bertam catchments. This could be attributed to both high slopes and annual rainfall amount in the region. The Ringel, Kingim Raja and Taman Desa are among the areas experiencing high susceptibility of landslides.

In order to ease identification of areas with specific problem, the susceptibility map was made in form of zones to easy decision while taking appropriate action. For instance, farming activities and/or any other soil disturbance operations at area under J24 grid (zone), appropriate conservation measures should be taken because is under high landslide susceptible. However, farming operations in K20 grid is relatively safe as it falls within low susceptible region to landslides. Furthermore, proximity to river appears to be an influencing factor to both erosion risk and landslide incidences from the inventory survey conducted. The same was observed here, where most of areas fall under high erosion and landslides region are situated close to the river. Field survey reveals that, farmers are conveying irrigation water from rivers to their farms using underground closed piping systems. Continues leakages due to broken pipes or improper coupling system result into surface and subsurface soil erosion and eventually lead to landslides. It was also noted that most of these activities are illegally conducted and therefore, management should take appropriate measure to conserve the soil and environment as a whole.

The susceptibility map indicates landslide-prone landforms within a large region with sufficient accuracy to permit recognition of general areas in which landslides occurrence may be expected. The map is not intended to replace site-specific engineering geologic and geotechnical investigations. As a regional-scale tool, the susceptibility map offers substantial benefits over previous susceptibility maps and zoning of landslidesusceptible terrain at Cameron Highlands.

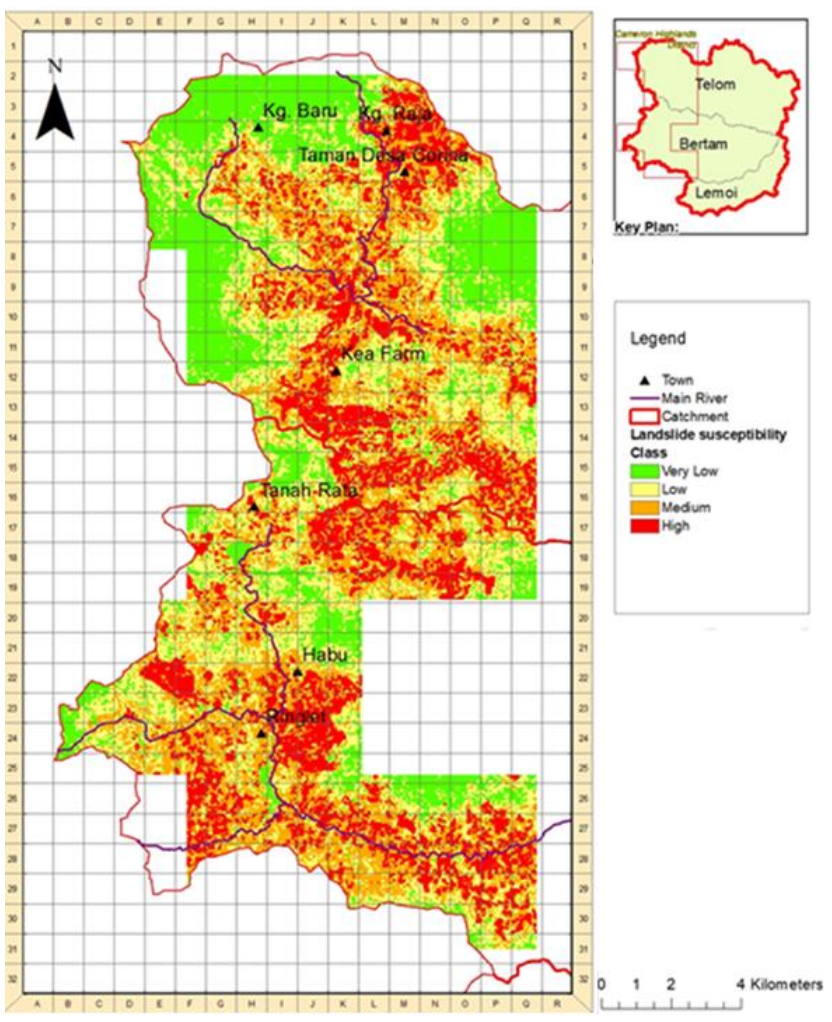

Figure 9 Land susceptibility map

\subsection{Erosion-Induced Landslide}

The result reveals that, the areas fall under high erosion-induced landslides include Kea Farm, Ringlet, Habu among others. Most of the farming activities are 
being conducted in those areas even though, there is high undulating lands. This indicates that, there is many cases of landslide as a result of excessive soil erosion in Cameron Highlands. Similar to landslide susceptibility situation, field observations on the erosion-induced landslide map shows that most erosion Induced landslides are happening near the river. For instance, farms located in Ringlet and its surroundings recorded high cases of erosion related landslides close to the river Bertem. The major issues compounding this problem includes improper conveyance of irrigation water as earlier discussed. Visual observation discloses that, many farmers are syphoning irrigation water to their various farms through surface and sub surface tubes. Close inspection shows that, some tubes were continuously leaking for long time. This weaken the subsurface slopes and led to eventual failure and landslides. Moreover, there were evidently incomplete drainage systems in some sheltered farms. The huge runoff collected from roofing tends to erode soil at downstream. Eventually, results into many cases of erosion and slope failures. Erosion-induced landslides map was prepared in form of zoning system in order to help for ease identification of farms with various sovereignty levels of erosion-induced landslide (Figure 10).

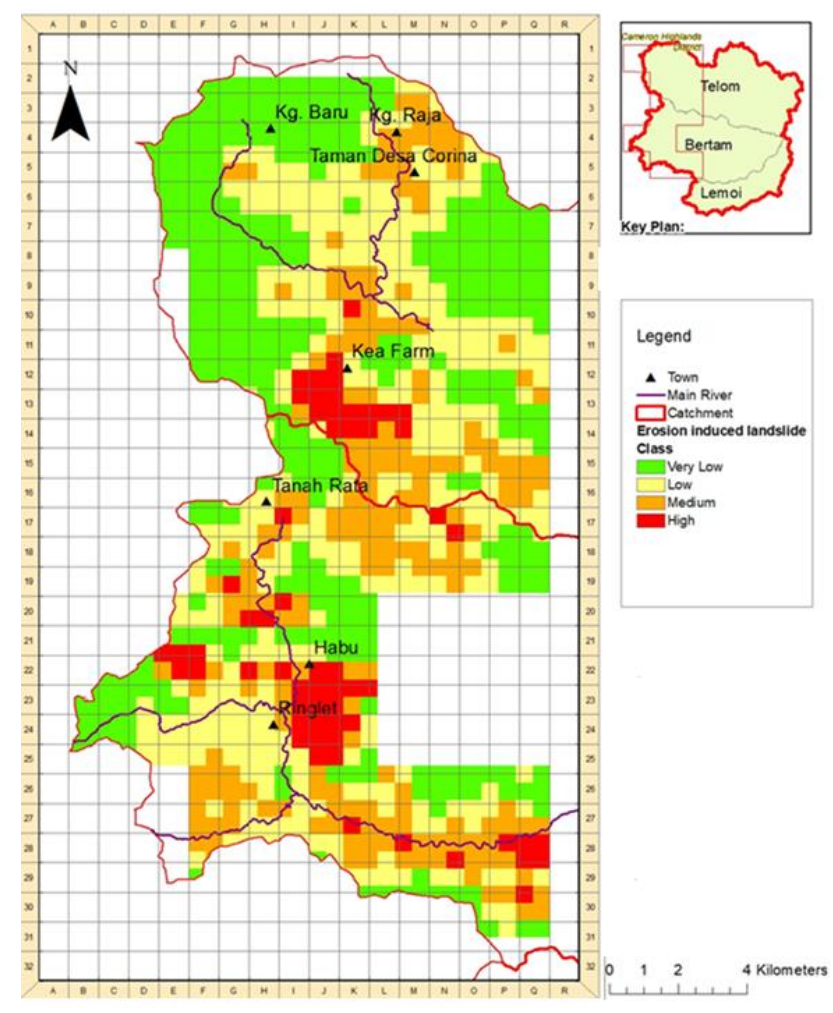

Figure 10 Erosion-induced landslide map

In the process to develop Erosion Induced Landslide Risk map, we combined the potential landslide event and its probability of occurrence using bivariate statistical analysis. The hazard risk categories are expressed as probability in qualitative forms (very low, low, moderate, and high). These qualitative categories are based on the soil erosion and susceptibility matrix scale as shown in Figure 11.

\section{Landslide Suceptibility}

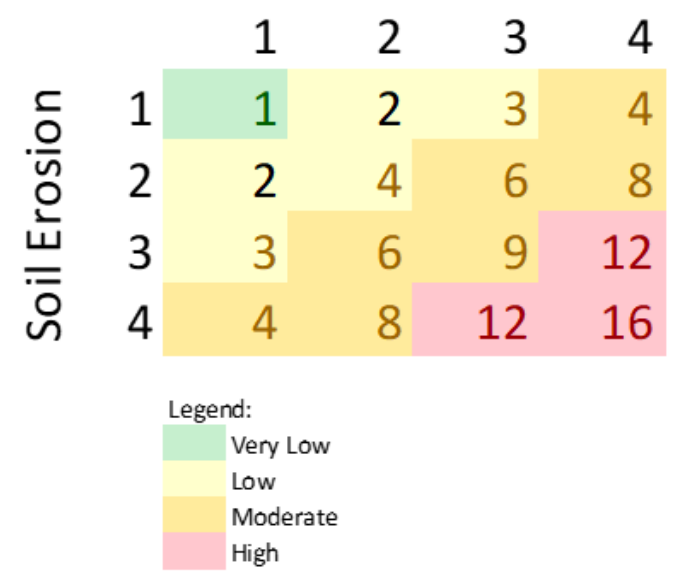

Figure 11 Probability of erosion-induced landslide occurrence

\subsection{CONCLUSION}

This study investigated the risk of erosion-induced landslides which is associated with agricultural activities on sheltered and open farmlands. Inventory records and field assessments are employed to come up statistics on landslides incidences at various locations within the study area. The study established that, more landslides cases occurred in areas under sheltered farming than in open farms. Moreover, soil erosion was found to play a significant role which triggers landslides occurrence. It is also, indicated that closeness to river or water body serves as an influential factor to emerging of landslides. This information could help to make holistic studies on erosion and landslides which might include both technical and social engagements.

\section{Acknowledgements}

This project is supported by UPM grant no. 9678700 . The supports from the Department of Irrigation and Drainage (DID), Department of Agriculture (DOA) Malaysia and Cameron Highlands Farmers' associations are appreciated.

\section{References}

[1] Crozier, M. J. 2018. A Proposed Cell Model for MultipleOccurrence Regional Landslide Events: Implications for Landslide Susceptibility Mapping. Geomorphology. 307(July): $\quad 3-11 . \quad$ https://doi.org/10.1016/j. geomorph.2018.02.001. 
[2] Rangsiwanichpong, P., Kazama, S., Ekkawatpanit, C., \& Gunawardhana, L. 2019. Evaluation of Cost and Benefit of Sediment based on Landslide and Erosion Models. CATENA. 173: 194-206. https://doi.org/https://doi.org/ 10.1016/j.catena.2018.10.010.

[3] Basher, L., Betts, H., Lynn, I., Marden, M., McNeill, S., Page, M., \& Rosser, B. 2018. A Preliminary Assessment of the Impact of Landslide, Earthflow, and Gully Erosion on Soil Carbon Stocks in New Zealand. Geomorphology. 307: 93106. https://doi.org/10.1016/j.geomorph.2017.10.006.

[4] Weebers, R. C. M., \& Idris, H. 2016. Decisions Made on the Development of the Hill Station of Cameron Highlands from 1884 till Present Day. Journal of Surveying, Construction and Property (JSCP). 7(1): 1-11.

[5] Hamzah, Z., Aminudin, C. Y., Saat, A., \& Wood, A. K. (2014). Quantifying Soil Erosion and Deposition Rates in Tea Plantation Area, Cameron Highlands, Malaysia Using 137Cs. The Malaysian Journal of Analytical Sciences. 18(1): 94-106. Retrieved from http://www.ukm.my/mjas/v18_nl/Che Yasmin.pdf.

[6] Nicu, I. C., \& Asăndulesei, A. 2018. GIS-based Evaluation of Diagnostic Areas in Landslide Susceptibility Analysis of Bahluieț River Basin (Moldavian Plateau, NE Romania). Are Neolithic Sites in Danger? Geomorphology. 314: 27-41. https://doi.org/10.1016/j.geomorph.2018.04.010.

[7] Othman, A. A., Gloaguen, R., Andreani, L., \& Rahnama, M. 2018. Improving Landslide Susceptibility Mapping Using Morphometric Features in the Mawat Area, Kurdistan Region, NE Iraq: Comparison of Different Statistical Models. Geomorphology. 319: 147-160. https://doi.org/10.1016/j.geomorph.2018.07.018.

[8] Mertens, K., Jacobs, L., Maes, J., Kabaseke, C., Maertens, M., Poesen, J., Vranken, L. 2016. The Direct Impact of Landslides on Household Income in Tropical Regions: A Case Study from the Rwenzori Mountains in Uganda. Science of the Total Environment. 550: 1032-1043. https://doi.org/10.1016/j.scitotenv.2016.01.171.

[9] Azim, F., Sattar, A., \& Kanwal, A. 2016. Impact of Climate Change on Sediment Yield for Naran Watershed. International Journal of Sediment Research. 31 (3): 212-219. https://doi.org/10.1016/j.jijsrc.2015.08.002.

[10] Nearing, M. A., Vining, R. C., Southworth, J., \& Pfeifer, R. A. 2005. Climate Change Impacts on Soil Erosion in Midwest United States with Changes in Crop Management. Catena. $61(2-3$ SPEC. ISS.): 165-184. https://doi.org/10.1016/j.catena.2005.03.003.

[11] Kukemilks, K. 2018. Landslide Inventory in the Abava Spillway Valley, Latvia. Estonian Journal of Earth Sciences. 67(3): 165. https://doi.org/10.3176/earth.2018.13.

[12] Wischmeier, W. H. and Smith, D. D. 1978. Predicting Rainfall Erosion Losses - A Guide to Conservation Planning. Agric. Handbook. No. 537, Washington D.C. 58.

[13] Su, Z., Xiong, D., Zhang, J., Zhou, T., Yang, H., Dong, Y., ... Shi, L. 2019. Variation in the Vertical Zonality of Erodibility and Critical Shear Stress of Rill Erosion in China's Hengduan Mountains. Earth Surface Processes and Landforms. 44(1): 88-97. https://doi.org/10.1002/esp.4482.

[14] Bols, P., 1978. The Is-erodent Map of Java and Madura, Belgian Technical Assistance Project ATA 105, Soil Research Institute, Bogor

[15] Razali, A., Syed Ismail, S. N., Awang, S., Praveena, S. M., \& Zainal Abidin, E. 2018. Land Use Change in Highland Area and Its Impact on River Water Quality: A Review of Case Studies in Malaysia. Ecological Processes. 7. https://doi.org/10.1186/s13717-018-0126-8.

[16] Barbosa, R. S., Marques Júnior, J., Barrón, V., Martins Filho, M. V., Siqueira, D. S., Peluco, R. G., Silva, L. S. 2019. Prediction and Mapping of Erodibility Factors (USLE and WEPP) by Magnetic Susceptibility in Basalt-derived Soils in Northeastern São Paulo State, Brazil. Environmental Earth Sciences. 78(1): 1-12. https://doi.org/10.1007/s12665-0188015-0.

[17] Shamshad, A., Leow, C. S., Ramlah, A., Wan-Hussin, W. M. A., \& Mohd Sanusi, S. A. 2008. Applications of AnnAGNPS
Model for Soil Loss Estimation and Nutrient Loading for Malaysian Conditions. International Journal of Applied Earth Observation and Geoinformation. 10: 239-252.

[18] Pradhan, B., Chaudhari, A., Adinarayana, J., \& Buchroithner, M. F. 2012. Soil Erosion Assessment and Its Correlation with Landslide Events Using Remote Sensing Data and GIS: A Case Study at Penang Island, Malaysia. Environmental Monitoring and Assessment. 184(2): 715-727. https://doi.org/10.1007/s10661-011-1996-8.

[19] Renard, K. G., Foster, G. R., and Weesies, G. A. 1997. Predicting Soil Erosion by Water; a Guide to Conservation Planning with the Revised Universal Soil Loss Equation (RUSLE), Agriculture Handbook No. 703, USDA-ARS, 404.

[20] DID. 2012). Government of Malaysia Department of Irrigation and Drainage Urban Stormwater Management Manual for Malaysia MSMA 2nd Edition. https://doi.org/http://dx.doi.org/10.1016/j.coldregions.201 2.06.005.

[21] Inoue, K., Mori, T., \& Mizuyama, T. 2012. Three Large Historical Landslide Dams and Outburst Disasters in the North Fossa Magna Area, Central Japan. International Journal of Erosion Control Engineering. 5(2): 134-143. https://doi.org/10.13101/ijece.5.134.

[22] Broothaerts, N., Kissi, E., Poesen, J., Van Rompaey, A., Getahun, K., Van Ranst, E., \& Diels, J. 2012. Spatial Patterns, Causes and Consequences of Landslides in the Gilgel Gibe Catchment, SW Ethiopia. Catena. 97: 127-136. https://doi.org/10.1016/j.catena.2012.05.011.

[23] Chen, H., Dadson, S., \& Chi, Y. G. 2006. Recent RainfallInduced Landslides and Debris Flow in Northern Taiwan. Geomorphology. 77(1-2): 112-125. https://doi.org/10.1016/j.geomorph.2006.01.002.

[24] Lin, W. T., Lin, C. Y., \& Chou, W. C. 2006. Assessment of Vegetation Recovery and Soil Erosion at Landslides Caused by a Catastrophic Earthquake: A Case Study in Central Taiwan. Ecological Engineering. 28(1): 79-89. https://doi.org/10.1016/j.ecoleng.2006.04.005.

[25] Malamud, B. D., Turcotte, D. L., Guzzetti, F., \& Reichenbach, P. 2004. Landslides, Earthquakes, and Erosion. Earth and Planetary Science Letters. 229(1-2): 45-59. https://doi.org/10.1016/j.epsl.2004.10.018.

[26] Yuan, X. Q., Duan, Z., \& Zhao, F. S. 2018. The Formation Mechanism of River Erosion-induced Loess Landslide. IOP Conference Series: Earth and Environmental Science. 186(3). https://doi.org/10.1088/1755-1315/186/3/012045.

[27] Prasannakumar, V., Vijith, H., Abinod, S., \& Geetha, N. 2012. Estimation of Soil Erosion Risk within a Small Mountainous Sub-watershed in Kerala, India, Using Revised Universal Soil Loss Equation (RUSLE) and Geo-Information Technology. Geoscience $\quad$ Frontiers. 3(2): 209-215. https://doi.org/10.1016/j.gsf.2011.11.003.

[28] Rahman, M. R., Shi, Z. H., \& Chongfa, C. 2009. Soil Erosion Hazard Evaluation-An Integrated Use of Remote Sensing, GIS and Statistical Approaches with Biophysical Parameters Towards Management Strategies. Ecological Modelling. 220(13-14): 1724-1734. https://doi.org/10.1016/j.ecolmodel.2009.04.004.

[29] Tamene, L., Adimassu, Z., Aynekulu, E., \& Yaekob, T. 2017. Estimating Landscape Susceptibility to Soil Erosion Using a GIS-based Approach in Northern Ethiopia. International Soil and Water Conservation Research. 5(3): 221-230. https://doi.org/10.1016/j.iswcr.2017.05.002.

[30] Aminuddin b. Y., M. H. Ghulam, W. Y. Wan Abdullah, M. Zulkefli and R. B. Salama. 2005. Sustainability of Current Agricultural Practices in the Cameron Highlands, Malaysia. Water, Air, and Soil Pollution. Focus. 5: 89-101. DOl: 10.1007/s $11267-005-7405-y$.

[31] Xu, L., XU, X., \& Meng, X. 2012. Risk Assessment of Soil Erosion in Different Rainfall Scenarios by RUSLE Model Coupled with Information Diffusion Model: A Case Study of Bohai Rim, China. Catena. 100: 74-82 https://doi.org/10.1016/j.catena.2012.08.012. 